\title{
Factors Affecting Wheat Producers' Water Conservation Behavior: Evidence from Iran
}

\author{
Yadgar Momenpour ${ }^{1}$, Shahla Choobchian ${ }^{1}{ }^{*}$ D , Hassan Sadighi ${ }^{1}$, Cristian-Valeriu Malos ${ }^{2}$, Ants-Hannes Viira ${ }^{3}$, \\ Alishir Kurban 4,5,6, (D) and Hossein Azadi $2,4,8$
}

1 Department of Agricultural Extension and Education, College of Agriculture, Tarbiat Modares University, 14155-6343 Tehran, Iran; Y.momenpoor@modares.ac.ir (Y.M.); H.sadighi@modares.ac.ir (H.S.)

2 Faculty of Environmental Science and Engineering, Babeş-Bolyai University, 400000 Cluj-Napoca, Romania; cristian.malos@ubbcluj.ro

3 Institute of Economics and Social Sciences, Estonian University of Life Sciences, 51014 Tartu, Estonia; ants-hannes.viira@emu.ee

4 Xinjiang Institute of Ecology and Geography, Chinese Academy of Sciences, 818 South Beijing Road, Urumqi 830011, China; alishir@ms.xjb.ac.cn (A.K.); hossein.azadi@ugent.be (H.A.)

5 Research Center for Ecology and Environment of Central Asia, Chinese Academy of Sciences, 818 South Beijing Road, Urumqi 830011, China

6 Sino-Belgian Joint Laboratory for Geo-Information, Urumqi 830011, China

7 University of Chinese Academy of Sciences, Beijing 100049, China

8 Department of Geography, Ghent University, 9000 Ghent, Belgium

* Correspondence: shchoobchian@modares.ac.ir; Tel.: +98-(21)-4829-2329; Fax: +98-(21)-4829-2200

Citation: Momenpour, Y.;

Choobchian, S.; Sadighi, H.; Malos,

C.-V.; Viira, A.-H.; Kurban, A.; Azadi,

H. Factors Affecting Wheat Producers' Water Conservation Behavior:

Evidence from Iran. Water 2021, 13,

3217. https://doi.org/10.3390/

w13223217

Academic Editor: Elias Dimitriou

Received: 22 August 2021

Accepted: 3 November 2021

Published: 13 November 2021

Publisher's Note: MDPI stays neutral with regard to jurisdictional claims in published maps and institutional affiliations.

Copyright: (c) 2021 by the authors. Licensee MDPI, Basel, Switzerland. This article is an open access article distributed under the terms and conditions of the Creative Commons Attribution (CC BY) license (https:/ / creativecommons.org/licenses/by/ $4.0 /)$.

\begin{abstract}
The present research aimed to identify and analyze the factors influencing water conservation behaviors (WCBs) and determine the most important ones. The research adopted a causalrelational method with a questionnaire compiled for data collection. The validity and reliability of the questionnaire based on the calculation of Cronbach's alpha for different sections were between 0.71 and 0.95. The statistical population included 5473 wheat farmers in Bukan Township, Iran. Krejcie and Morgan tables were used to calculate the sample size of 357 people. All these farmers have key information about the effects of climate change (e.g., drought) and are pioneers in using adaptation and water conservation strategies in wheat production. In this study, the sample size was determined using stratified sampling method with proportional assignment. The questionnaire validity was approved by the validity expert board. According to the findings of the exploratory factor analysis, the most important factors influencing WCBs of wheat producers included "institutional", "economic", "natural", "extensional", "social", "attitudinal", and "self-identity" ones. These seven factors together accounted for $47.498 \%$ of the variance in WCBs of wheat producers. The relationship between independent variables and wheat growers' WCBs was determined by Pearson correlation coefficients. According to the results, economic, institutional, natural, attitudinal, social, and self-identity factors had a significant relationship with WBC at $1 \%$ error level. The regression results also showed that among the studied variables, economic and extensional factors had the greatest impact on wheat growers' WCBs. The results can help managers and planners determine policies that focus more on economic and extensional factors that have been neglected in previous studies.
\end{abstract}

Keywords: wheat farmers' behavior; exploratory factor analysis; water resources

\section{Introduction}

As population growth continues around the world, there are many concerns about water scarcity. This trend shows the current need for saving water resources to prevent significant water shortages in the future [1,2]. In many countries, the scarcity of water resources places many constraints on the economic development of arid and semi-arid regions [3,4]. Worldwide, most land is used for the production of food (about $40 \%$ ). High pressure from intense agricultural activities on land has made it one of the most important 
concerns of policymakers, environmentalists, and the scientific community. At present, about 16.5 million hectares of Iranian land are used for agricultural production [5]. Iran is an important country in the Middle East in terms of the need for biodiversity protection [6]. Due to its location in arid and semi-arid regions in the Middle East, Iran has been faced with frequent water shortages and droughts $[7,8]$ so that its average annual rainfall is as low as $250 \mathrm{~mm}$ [9]. In addition, this country is struggling with numerous environmental problems including the constant drawdown of groundwater levels [10], drying of lakes, wetlands, rivers, and land subsidence [11]. Iran is facing a widespread water crisis that is likely to intensify in the coming years, which causes many economic, social, environmental, and political challenges. Iran is also in a very critical situation in terms of groundwater resources due to over-exploitation while it is among the top groundwater owners in the world [11].

In recent years, many parts of Iran have suffered from a serious water crisis due to decreased rainfall, shortage of water sources management, groundwater discharge, etc. [12]. However, several political, economic, social, and ecological factors have been responsible for water scarcity in the region [13]. In Iran, 70\% of the total water harvest is done by agricultural activities, and one of the effective ways to save water is to increase farmers awareness. Hence, the conservation of water resources by farmers is crucial for the success of water conservation programs in Iran and it should be one of the main responsibilities and goals of farmers [14]. Although the development and expansion of agriculture is a stimulus for direct human use of nature, livestock production, and food production, the expansion of agriculture is largely the main cause of environmental degradation and destruction [15]. The clear result of maximum resource utilization is the loss of most resources, which are necessary for the agricultural sector. These agro-environmental problems reduce agricultural sustainability [16].

Due to concerns about climate change and the increasing human population, drinking water resources are considered a valuable part of nature that must be saved effectively [17]. The protection of water resources is an important and essential component of effective management and a sustainable environment. Climate change is expected to reduce the reliability of water resources because of the increased variety of precipitation events. The protection of water resources will therefore become increasingly essential. Given the necessity of water conservation for a sustainable environment, it is imperative to efficiently manage water resources by changing the behavior of water conservation, for which it is important to recognize the underpinning factors. Awareness of the factors that reduce water resources will inform water managers, policymakers, and governments on how to conserve water resources and be aware of the needs of the present water resources. Yet, relatively limited research has been done, despite the importance of increasing watersaving behaviors [18]. Many countries (e.g., Australia and New Zealand) have encouraged consumers to play a role in saving water and other natural resources. It has been shown that behavior change methods can be very helpful in this regard. The behavior change science aims to develop and implement (interventionist) programs to produce desired behavioral changes in the target people or community [17].

Environmental degradation is a common problem in which individual consumption measures have little effect on a common source. However, the cumulative effect of such degradation has a considerable negative impact on the environmental resources and their future survival. Therefore, the goal of individuals is in conflict with society. The latent dilemma is useful in transforming individual rational behavior into social group behavior, and this, in turn, requires large-scale behavioral changes [19]. With the development of environmental awareness, the need to understand how humans respond to environmental degradation and pollution is felt more than ever [20]. With long-term planning and policymaking, as well as managing farmers' behaviors and directing them towards environmental protection and sustainability, the severity of environmental degradation can be reduced, and an effective step can be taken towards environmental protection and sustainability. 
In the last four decades, many researchers have studied the negative impacts of humans on the Earth's capacity. Therefore, it can be concluded that climate aggravation, pollution and the reduction of resources are rooted in humans' misbehavior towards the natural environment [21]. In addition, extensive research in the literature shows that a wide range of farmers' conservation goals and behaviors have recently been examined. Some of these behaviors include intent to perform non-distributive environmental cultivation practices, technology adoption, sustainable consumption, waste management, renewable energy acceptance, and intent to save water [22-26]. However, in water consumption, little attention has been paid to farmers' water conservation behaviors (WCBs). Therefore, success in natural resource conservation programs and their optimal use requires understanding the various dimensions of human behavior [27]. It is important to consider all the factors that influence and relate to a particular type of decision-making. In general, factors that may influence farmers' decisions include agriculture and environmental regulations (norms related to how to interact with nature), economic factors (costs, prices, subsidies, production, and main source of income), physical location (soil quality, drainage, topography, and production factors), social factors (farmers' age, level of education, information resources, and length of stay in the village), and personal-psychological factors (norms, beliefs, risk perception, values, goals, type of decision-making, and emotions) [28].

In Iran, due to the current environmental situation, especially the excessive use of pesticides and chemical fertilizers in agriculture, unstable conditions have arisen, and it is necessary to consider environmental sustainability and identify the effective factors. Bukan Township, located in the south of West Azerbaijan province, is considered a mountainous area due to its natural conditions and topography, and consequently, most parts of this township, especially its agricultural lands, have a steep slope. Therefore, more attention should be paid to the behavior of farmers in the field of soil protection. In the past decades, several effective WCBs have been created and used by farmers. However, the acceptance of these WCBs in Iran is low and the reasons for this vary depending on the location. In Iran, few works have been done on the farm to inspect and approve the WCB. In this regard, most adoption studies are moderated and there is no universal model to study the factors influencing the water conservation behavior of wheat producers in Iran. In addition, we did not find any adoption studies that include factors that affect the water conservation behavior of wheat producers in Iran. Previous studies have included the series of the intensity of the variables that are independent and used in the adoption of models based on technology. Furthermore, these studies showed variables that provide a farmer's mental understanding along with socioeconomic variables, economic conditions, and individual characteristics. Therefore, a proper case has been made for a greater and more extensive awareness of farmers' WCBs. A farmer's decision to invest in soil and WCB is influenced by a series of institutional, socio-economic, physical, and attitudinal factors.

This study takes a wider approach and provides a framework for analysis that contains a broader range of factors that reflect the socioeconomic, individual, and household features of farmers, along with the factors that reflect farmers' perceptions. According to the statistics obtained from the Agricultural Jihad Organization of Bukan Township, the farmers' rate of water use per hectare is above average. Furthermore, the obsolescence of irrigation systems has increased costs and water consumption on farms. By considering the vital role of water conservation in food security and agricultural sustainability, adequate water management, and mitigation of climatic changes, understanding the factors that affect water conservation behavior is crucial. The awareness of these factors helps managers in the water sector, government officials, and public policymakers to understand how to properly promote water-conservation behaviors and diminish the demand to supplement available water resources $[29,30]$. In this regard, extensive research has not been conducted on water conservation behaviors in Iran. Therefore, the current paper aimed to test a comprehensive model of WCBs. According to the results of Aprile and Fiorillo [31] and Asfaw and Neka [32], in this study, the respondents from diverse geographical areas with larger sample sizes have been selected to enhance the generalized findings. First, the current 
study contributes to expanding the literature on WCBs by smallholder farmer households in Iran. Second, the results of this study could increase the evidence of the importance of elements associated with farmers' understandings of the implementation of WCBs and the implications of such policies. Third, this study covers a variety of socio-economic determinants that might affect the WCBs of wheat producers, and the results can be generalized to other similar areas. Thus, the findings of this study provide a unique data set, address the implications for WCB adoption of a multidimensional prospect, and serve as an opening point for policy invasions to properly manage WCB adoption between the smallholder farming households.

Specifically, the present study seeks to identify and investigate the factors that have the greatest role in explaining the WCBs of wheat farmers in Bukan Township by studying their environmental behaviors. Therefore, the aim of this study is to identify and analyze the factors affecting environmental behaviors and determine the most important factors affecting WCBs. By providing some solutions to change people's behaviors, especially farmers', and aligning their behaviors to be more compatible with the environment, the intensity and speed of environmental degradation can be significantly reduced. According to the Bukan Agricultural Jihad Organization, reducing water consumption and protecting water resources are the two main goals of the organization. This research used exploratory factor analysis to identify the factors affecting WCBs and the regression technique to investigate the effect of each of these factors on WCBs.

\section{Research Background}

Given the warnings that the next war will be the war on water, the issue of water conflict is predicted to be the most important threat to human life [33]. Environmental issues, such as water scarcity, create a set of social perspectives. To gain knowledge and a correct understanding of these issues at the level of individuals and groups in society, social studies should be done [34]. Over the years, many researchers have attempted to identify the underlying mechanisms that shape human behavior from a behavioral psychology perspective. How behaviors are determined is a fundamental issue in social psychology (Table 1).

Table 1. A brief list of research on water conservation and their findings.

\begin{tabular}{|c|c|c|}
\hline References & Title & Findings \\
\hline Yazdanpanah et al. [35] & $\begin{array}{l}\text { Investigate the factors that facilitate or } \\
\text { hinder water saving activities by } \\
\text { Iranian farmers }\end{array}$ & $\begin{array}{l}\text { Income or productivity may inspire farmers to } \\
\text { take protecting measures. }\end{array}$ \\
\hline Shiferaw et al. [36] & $\begin{array}{l}\text { Adaptation and Acceptance of Natural } \\
\text { Resource Innovation Management in } \\
\text { Smallholder Agriculture }\end{array}$ & $\begin{array}{c}\text { The research emphasized the acceptance of } \\
\text { conservation methods by farmers and addressed } \\
\text { issues such as policies, infrastructure, } \\
\text { organizations, services, markets, innovations, } \\
\text { personal and professional characteristics, and } \\
\text { natural conditions. }\end{array}$ \\
\hline Gouldson et al. [37] & $\begin{array}{l}\text { Ecological modernization and policy } \\
\text { learning in Hong Kong }\end{array}$ & $\begin{array}{l}\text { It claimed that we need capacity building for } \\
\text { environmental renewal and policy-making to } \\
\text { address the increasingly adverse environmental } \\
\text { impacts we face. }\end{array}$ \\
\hline Daloğlu et al. [38] & $\begin{array}{c}\text { Development of a farmer typology of } \\
\text { agricultural conservation behavior in the } \\
\text { American Corn Belt }\end{array}$ & $\begin{array}{l}\text { Land ownership, land size, source of income, } \\
\text { and communication networks are the consistent } \\
\text { components that influence environmental } \\
\text { protection decisions. }\end{array}$ \\
\hline
\end{tabular}


Table 1. Cont.

\begin{tabular}{|c|c|c|}
\hline References & Title & Findings \\
\hline Moshtagh and Mohsenpour [39] & $\begin{array}{l}\text { Community viewpoints about water } \\
\text { crisis, conservation and recycling: a case } \\
\text { study in Tehran }\end{array}$ & $\begin{array}{l}\text { There is a relationship between attitudes to age, } \\
\text { education, and gender and water management. } \\
\text { Developing public knowledge and clarity will } \\
\text { help improve social trust and accurate attitudes } \\
\text { and encourage more responsible behaviors } \\
\text { towards water resources. }\end{array}$ \\
\hline Momenpour et al. [40] & $\begin{array}{l}\text { Structural analysis of the role of } \\
\text { educational-extension and psychological } \\
\text { components on the environmental } \\
\text { behavior of wheat growers in west } \\
\text { Azerbaijan province, Iran }\end{array}$ & $\begin{array}{l}\text { The results showed that self-identity and } \\
\text { environmental attitudes are influential } \\
\text { components in the field of environmental } \\
\text { behavior. Moreover, extension-educational } \\
\text { factors have a vital and decisive influence on } \\
\text { environmental behavior. }\end{array}$ \\
\hline Liu et al. [41] & $\begin{array}{l}\text { The role of social capital in encouraging } \\
\text { residents' pro-environmental behaviors } \\
\text { in community-based ecotourism }\end{array}$ & $\begin{array}{l}\text { There was a direct influence of economic } \\
\text { interests on the environmental behavior of } \\
\text { citizens and a low influence of social resources } \\
\text { on environmental behavior. }\end{array}$ \\
\hline Valizadeh et al. [42] & $\begin{array}{l}\text { Farmers' Active Participation in Water } \\
\text { Conservation: Insights from a Survey } \\
\text { among Farmers in Southern Regions of } \\
\text { West Azerbaijan Province }\end{array}$ & $\begin{array}{l}\text { The findings indicated that ethical norms, social } \\
\text { constraints, location dependence, social } \\
\text { responsibility, quality of extension services, and } \\
\text { satisfaction with water resources management } \\
\text { have a significant influence on the active } \\
\text { cooperation of farmers in saving } \\
\text { water consumption. }\end{array}$ \\
\hline Dienes [43] & $\begin{array}{c}\text { Perception of the environmental attitude, } \\
\text { perception of social norms, perception of } \\
\text { the environment, understanding the } \\
\text { natural environment }\end{array}$ & $\begin{array}{l}\text { The results indicate that economic factors have a } \\
\text { moderating effect on climate change concerns } \\
\text { and the necessary measures to address them. }\end{array}$ \\
\hline
\end{tabular}

As was mentioned earlier, many environmental threats, resource degradation, and environmental pollution are the consequences of human behavior. These environmental problems can be reduced by changing human behavior. The first step to change a behavior is to identify its effective factors. Rehabilitation, development, and exploitation of natural resources are incomparable. Therefore, the need to pay attention to the factors affecting the occurrence of environmental behaviors of farmers is of considerable importance. In the present study, a set of variables affecting WCBs based on previous research, and contemporary theories of environmental sociology and environmental psychology were used to address the following question: Why do farmers, consciously or unconsciously, get involved in environmental degradation? Furthermore, the research provides solutions to lead farmers to responsible behaviors towards the environment. A review of previous studies shows that significant efforts have been made, while many factors remain neglected. The previous literature has concentrated more on the psychological and internal aspects of behavior, and the external factors influencing behavior have been ignored. In addition, most previous research studies have used previous behavioral models as a basis, which has limited their freedom to explore new factors. This has been addressed in the present research. On the other hand, no previous study has dealt with the relative importance of the external and internal factors affecting behavior as a whole. These effects have carefully been considered in this research, which shows the innovation of this research in science, tools, and methods. Moreover, previous studies have considered WCBs to be the same for all farmers, which is one of their limitations because the factors affecting wheat farmers' WCBs are not the same as those affecting the medicinal plant farmers' WCBs. Therefore, it is a drawback to present a model for all types of farmers. This is another issue considered in this study.

The agricultural sector in Iran consumes the majority of water resources (about 70\%). Data show that groundwater abstraction has grown significantly over the last four decades. 
Furthermore, due to the geographical situation of the region, which has been facing a lack of rainfall and drought in recent years, farmers' emphasis on more production leads to intensified pressure on water resources in the region. Given that the main and final decision-makers on how to use water are farmers or humans, studying their behaviors and identifying factors that have a significant impact on their behaviors can have a considerable effect on the protection and management of water supply.

\section{Materials and Methods}

The research method used in this study was causal relational research, in which the factors affecting WCBs were first explored through exploratory factor analysis. Indeed, the factors that had been neglected in previous studies were included in this research. Then, the correlation of the explored factors with WCBs was measured. At the next step, the relative importance of each factor was investigated by the regression technique, which is one of the innovations of the present study. In this study, the statistical population included wheat farmers in Bukan Township in West Azerbaijan province, Iran $(N=5473)$ (Figure 1). All these farmers have dealt with the consequences of climate change (especially drought). It should be mentioned that these farmers were all identified as elite and informant experts who provided the study with the point and key information. The sample size consisted of 357 participants, who were determined by Krejcie and Morgan tables [44]. The samples were chosen using a stratified random sampling method with proportional allocation. The stratified random sampling method was chosen because of its high accuracy in sample estimation. Moreover, the stratified sampling method lets researchers classify the study population so as to reduce the research time and costs. In addition, the low variance of the categories enhances the sampling accuracy [45]. Furthermore, due to the differences between classes in the statistical population and the reduction of variance in the floors, it was necessary to use the stratified random sampling method with proportional allocation. Table 2 shows the details of statistical information of the population.

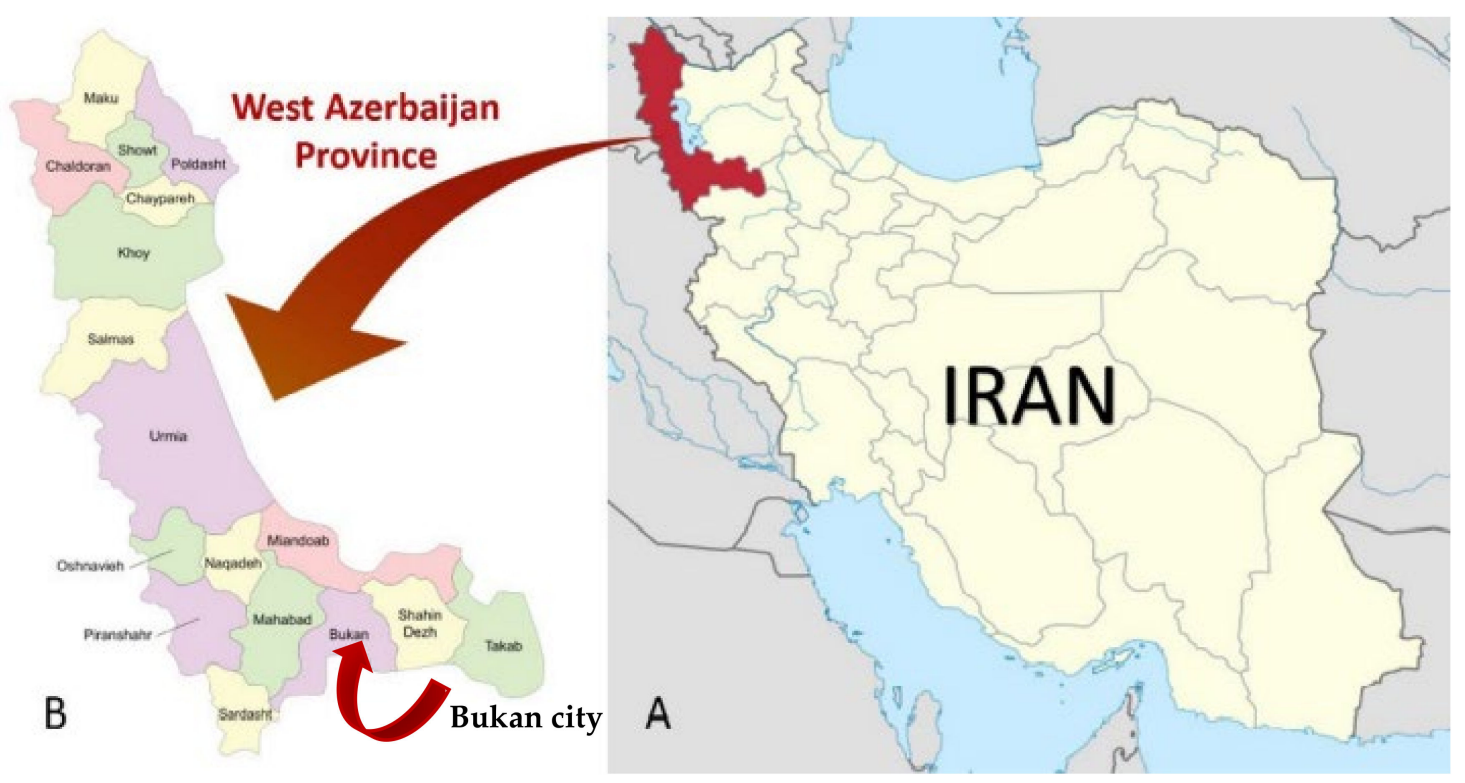

Figure 1. The study area. Source: Nejadrahim et al. [46]. (A): Geographical location of the study area in Iran. (B): Geographical location of the study area in West Azerbaijan Province. 
Table 2. The sample size according to stratified random sampling.

\begin{tabular}{|c|c|c|c|c|c|c|}
\hline Township & Sub-Counties & $\begin{array}{l}\text { Total Number of } \\
\text { Sub-Counties }\end{array}$ & $\begin{array}{c}\text { Total } \\
\text { Number of } \\
\text { Villages }\end{array}$ & $\begin{array}{c}\text { Total } \\
\text { Number of } \\
\text { Farmers }\end{array}$ & $\begin{array}{l}\text { Proportioned } \\
\text { Number of } \\
\text { Samples in } \\
\text { Each } \\
\text { Sub-County }\end{array}$ & $\begin{array}{l}\text { Total Number } \\
\text { of Selected } \\
\text { Villages }\end{array}$ \\
\hline Bukan & $\begin{array}{c}\text { Akhtachi, Eastern } \\
\text { Akhtachi, Mahali } \\
\text { Akhtachi, Ale } \\
\text { Timur, Ale Gavork, } \\
\text { Dehbikri, } \\
\text { Fezalahbaigi }\end{array}$ & 7 & 175 & 23306 & 245 & 16 \\
\hline
\end{tabular}

The required data were collected through a questionnaire and its accuracy was determined using the opinions of the relevant panel of experts. Furthermore, after conducting a pre-test among farmers in Mahabad Township (including 30 farmers), which was similar to the studied population in terms of cultural, natural, and climatic conditions as well as socio-economic background (to determine the reliability of the measurement tool), the Cronbach's alpha coefficient was estimated between 0.71 and 0.95 , indicating the acceptable reliability of the research instrument. SPSS22 software was used to analyze the collected data. The exploratory factor analysis technique and regression were employed in the data analysis step.

\section{Results}

\subsection{Descriptive Statistics}

The frequency distribution of the study population shows that $79.6 \%$ of the respondents were male. In terms of education level, most of them (31.9\%) had a diploma. In terms of living location, $71.8 \%$ lived in rural areas, $9.6 \%$ in urban areas, and $18.6 \%$ in urban and rural areas. In terms of land ownership, $77.9 \%$ owned their farms while $22.1 \%$ had rented them. In terms of agricultural work experience, wheat farmers with 15-10 years of experience had the highest frequency $(31.9 \%)$, and in general, they had an average experience of 14.36 years. Findings also showed that wheat farmers' age group of $<30$ years $(37.8 \%)$ had the highest frequency, whereas the lowest frequency belonged to the group of over 50 years $(17.1 \%)$.

\subsection{Factor Analysis of Variables Affecting Wheat Farmers' WCBs}

To determine the importance of each item of wheat farmers' WCBs, the coefficient of variation was used (Table 3). Factor analysis was used to reduce the number of research variables to fewer factors and determine the contribution of each factor in the incidence of WCBs. For this purpose, the variables in seven areas of institutional, economic, natural, extensional, social, attitudinal, and self-knowledge were considered in factor analysis (Figure 2). To determine the share of each factor, the percentage of variance explained by each factor of the total variance was used, and according to the amount of variance defined by all factors, the number of factors affecting the WCBs of wheat farmers was determined. The calculations showed that the internal consistency of the data was appropriate, and Bartlett's statistic was significant at the $1 \%$ level. Furthermore, the KMO was larger than 0.7, which shows the sampling adequacy [47] (Table 4).

Based on the findings presented in Table 5 about water protection, the variables included in the analysis were classified into seven factors. The first factor with an eigenvalue of 9.790 explained $20.396 \%$ of the total variance. Moving from the first factor to the seventh factor reduced the eigenvalues and the percentage of variance explained by each factor. However, it was added to the percentage of the total variance so that the seven extracted factors explained a total of $47.489 \%$ of the total variance. Table 6 presents the status of the variables in the factors, assuming the inclusion of the variables with a factor loading of 
$>0.5$ after rotating the factors by the Varimax method and naming the factors. However, it should be noted that after rotation (Varimax), some variables were excluded from the process of analysis because of their low factor loading (less than 0.5) and their insignificant correlation with other variables. Considering the percentage of variance explained, the institutional factor had the largest share in the set of components affecting WCBs.

Table 3. The ranking of water protection behavior items.

\begin{tabular}{ccccc}
\hline Rank & Items & Sources & Mean * & SD \\
\hline 1 & I use pipes for water transfer. & {$[4]$} & 3.52 & 1.17 \\
2 & I cultivate more tolerant crops. & {$[4]$} & 3.4 & 3.39 \\
3 & I always monitor irrigation carefully. & {$[4]$} & 3.29 & 1.054 \\
4 & I repair old canals. & {$[4]$} & 3.28 & 1.042 \\
5 & I use new irrigation methods. & Self-developed & 3.17 & 1.065 \\
6 & I kill weeds around streams. & Self-developed & 3.17 & 1.005 \\
7 & I store rainwater in small pools. & {$[4]$} & 3.11 & 1.182 \\
8 & I irrigated at night/evening or in the & {$[4]$} & 2.18 & 1.112 \\
9 & morning (cooler hours of the day). & I reuse wastewater. & 1.43 & 1.469 \\
10 & I do not irrigate when it is raining. & {$[4]$} & 1.374 \\
\hline
\end{tabular}

* Means were measured by the Likert scale (0: not at all, 1: very low, 2: low, 3: medium, 4: high, 5: very high).

Table 4. The KMO values, Bartlett's test, and the significance level.

\begin{tabular}{cccc}
\hline Collection under Analysis & KMO Value & Bartlett Value & Significance Level (Sig) \\
\hline Components affecting WCBs & 0.869 & 6045.906 & 0.00 \\
\hline \multicolumn{2}{c}{ Source: research findings. }
\end{tabular}

Table 5. Extracted factors along with specific values, percentage of variance, and cumulative variance.

\begin{tabular}{cccc}
\hline Factors & Eigenvalue & Percentage of Variance & The Cumulative Percentage \\
\hline Institutional & 9.79 & 20.396 & 20.396 \\
Economic & 2.807 & 5.848 & 26.244 \\
Natural & 2.483 & 5.174 & 31.418 \\
Self-identity & 2.39 & 4.978 & 36.397 \\
Extensional & 2.011 & 4.19 & 40.586 \\
Social & 1.825 & 3.804 & 44.389 \\
Attitudinal & 1.492 & 3.109 & 47.498 \\
\hline
\end{tabular}

Source: research findings.

Table 6. Characteristics of factors extracted from the factor analysis.

\begin{tabular}{|c|c|c|}
\hline Component & Items & Coefficient \\
\hline \multirow{8}{*}{ Institutional } & Environmental laws reduce my profits. & 0.695 \\
\hline & $\begin{array}{c}\text { General government policies are more about increasing production } \\
\text { than protecting WCBs. }\end{array}$ & 0.67 \\
\hline & $\begin{array}{c}\text { Proper pricing of inputs and products (less harmful) encourages people } \\
\text { to support WCBs. }\end{array}$ & 0.641 \\
\hline & $\begin{array}{l}\text { Legal restrictions should be considered on the use of agricultural products } \\
\text { with high water consumption. }\end{array}$ & 0.584 \\
\hline & It is necessary to establish a national strategy for the use of environmental methods. & 0.555 \\
\hline & Although environmental laws reduce my production, I still follow them. & 0.55 \\
\hline & There are policies to prevent unauthorized abstraction of water resources. & 0.532 \\
\hline & $\begin{array}{c}\text { Government subsidies for green production practices reduce the } \\
\text { use of artificial inputs. }\end{array}$ & 0.527 \\
\hline
\end{tabular}


Table 6. Cont.

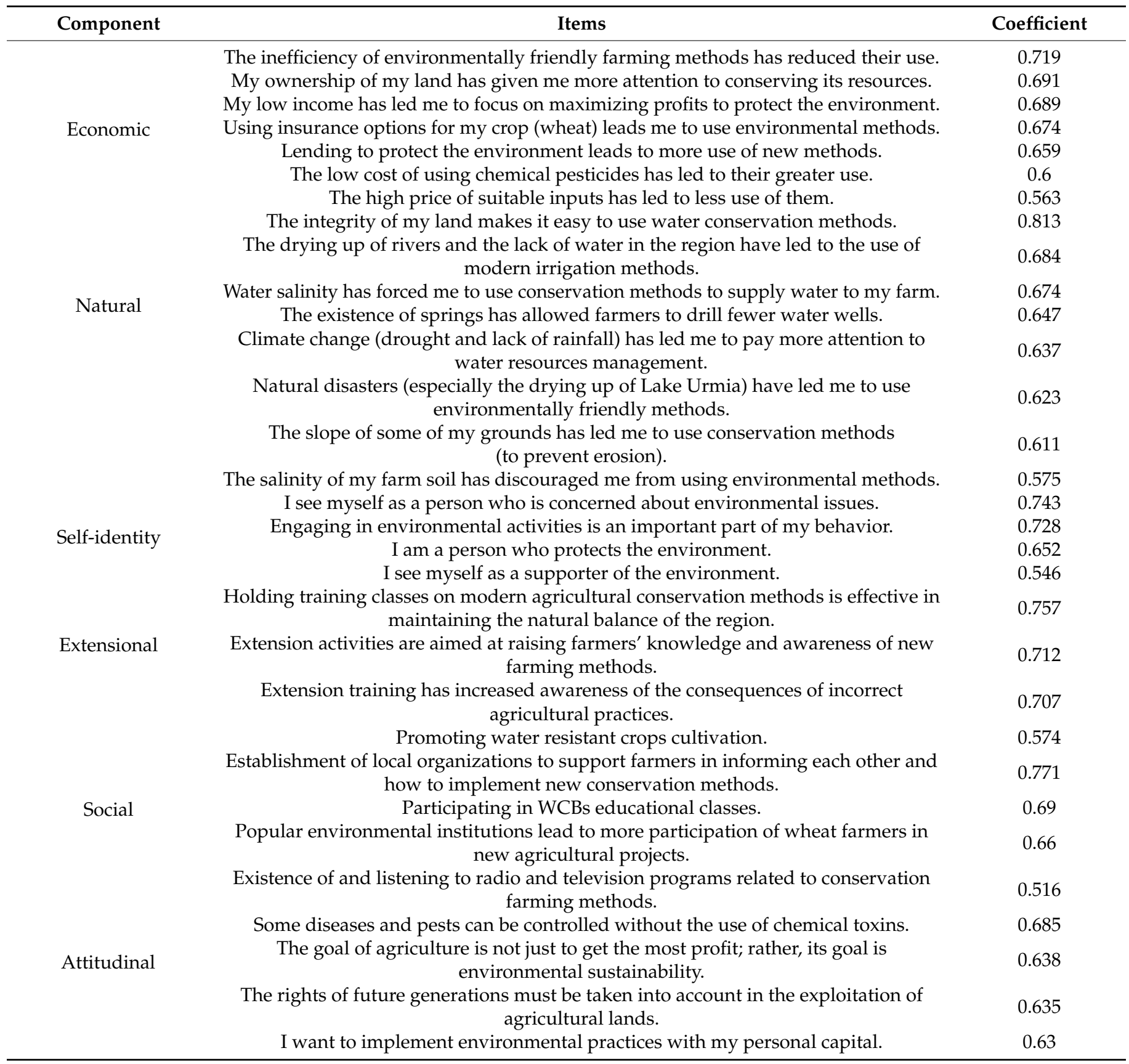

Source: the study findings.

According to the outcomes of factor analysis of components affecting the WCBs of wheat farmers in Table 4, the components affecting WCBs were categorized into seven factors, including "institutional", "economic", "natural", "self-identity", "extensional", "social", and "attitudinal" ones, listed in the order of importance. The institutional factor had the most important role in explaining wheat farmers' WCBs. The findings show that the institutional factor (the first factor) includes the issues such as the need to establish a national strategy in the field of environmental protection, appropriate pricing of environmentally friendly inputs, the government's general policy to increase production rather than protecting the environment, the adoption of policies regarding the unauthorized extraction of natural resources, paying attention to legal restrictions on the use of crops with high water requirement, the cumbersome conditions of environmental laws, and 
production reduction. This factor accounts for $20.396 \%$ of the variance in the components affecting the WCBs of wheat farmers.

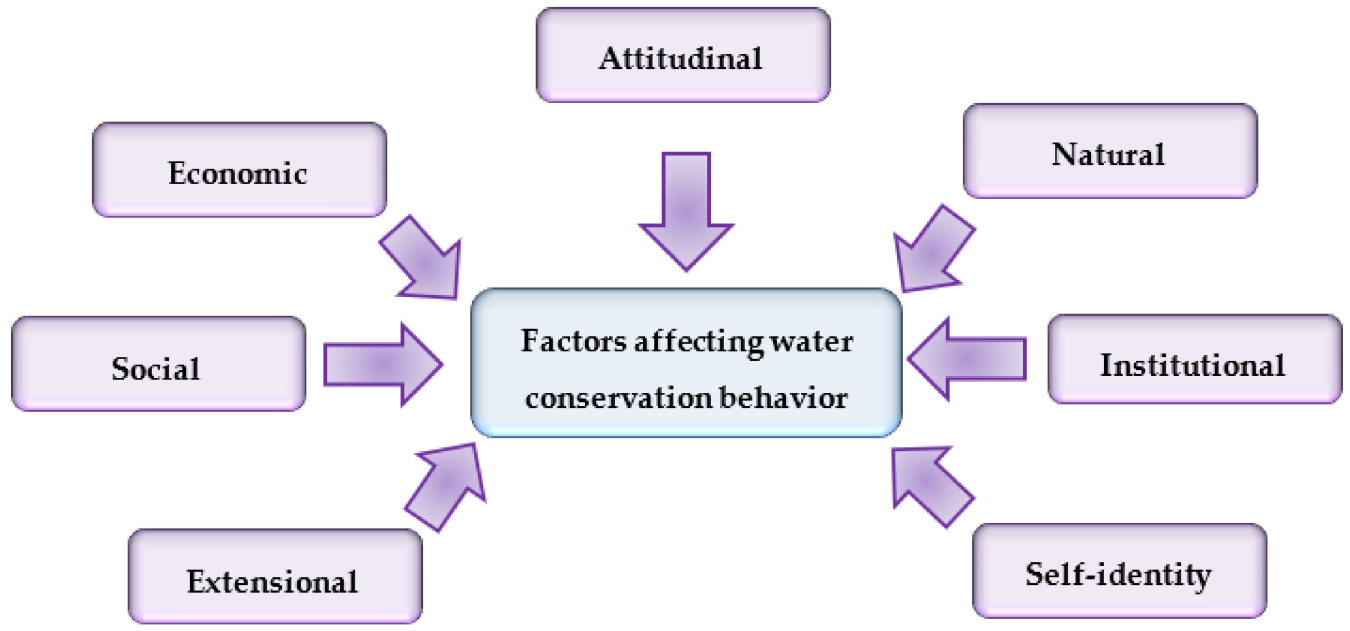

Figure 2. Mind map of factors affecting the water conservation behavior of wheat farmers.

The economic factor (the second factor), encompassing the unprofitability of environmental methods, low income due to non-use of these methods, lending, land ownership, crop insurance, the low hassle of pesticide use, and high input prices, explained more than $5 \%$ of the total variance, which cumulatively with the previous factor captured more than $26 \%$ of the total variance in the components affecting WBC. Furthermore, the relationship between independent research variables and wheat WCBs variables was used to determine Pearson correlation coefficients. According to the results, there is a considerable relationship among the dependent variable and other variables, including economic, institutional, natural, attitudinal, social, and extensional factors and self-identity of wheat farmers in Bukan Township at the $0.01 \%$ error level (Table 7 ).

Table 7. The results of the correlation analysis.

\begin{tabular}{|c|c|c|c|c|}
\hline The First Variable & The Second Variable & Correlation Coefficient (r) & Significance Level & Type of Test \\
\hline Economic factor & & $0.529 * *$ & 0.001 & \\
\hline Institutional factor & & $0.501 * *$ & 0.001 & \\
\hline Natural factor & & $0.476^{* *}$ & 0.001 & \\
\hline Attitudinal factor & WCBs & $0.355^{* *}$ & 0.001 & Pearson \\
\hline Extensional factor & & $0.466^{* *}$ & 0.001 & \\
\hline Social factor & & $0.275^{* *}$ & 0.001 & \\
\hline Self-identity factor & & $0.274^{* *}$ & 0.001 & \\
\hline
\end{tabular}

** = At a significance level of $95 \%$. Source: research findings.

Multiple regression was used to predict the changes in the WCBs of wheat farmers and to investigate the relationship between the factors derived from factor analysis. The method used was stepwise regression [48]. As Table 8 shows, out of seven extracted factors, four factors were included in the regression equation. Furthermore, one unit of change in economic, extensional, institutional, and natural factors will result in 0.294, 0.278, 0.191, and 0.179 units of change in the variance of wheat farmers' WCBs, respectively (Figure 3). The regression equation of the factors derived from the exploratory factor analysis was obtained as follows:

$$
\mathrm{Y}=-17.508+1.783(\mathrm{X} 1)+2.732(\mathrm{X} 2)+0.925(\mathrm{X} 3)+0.460(\mathrm{X} 4)
$$




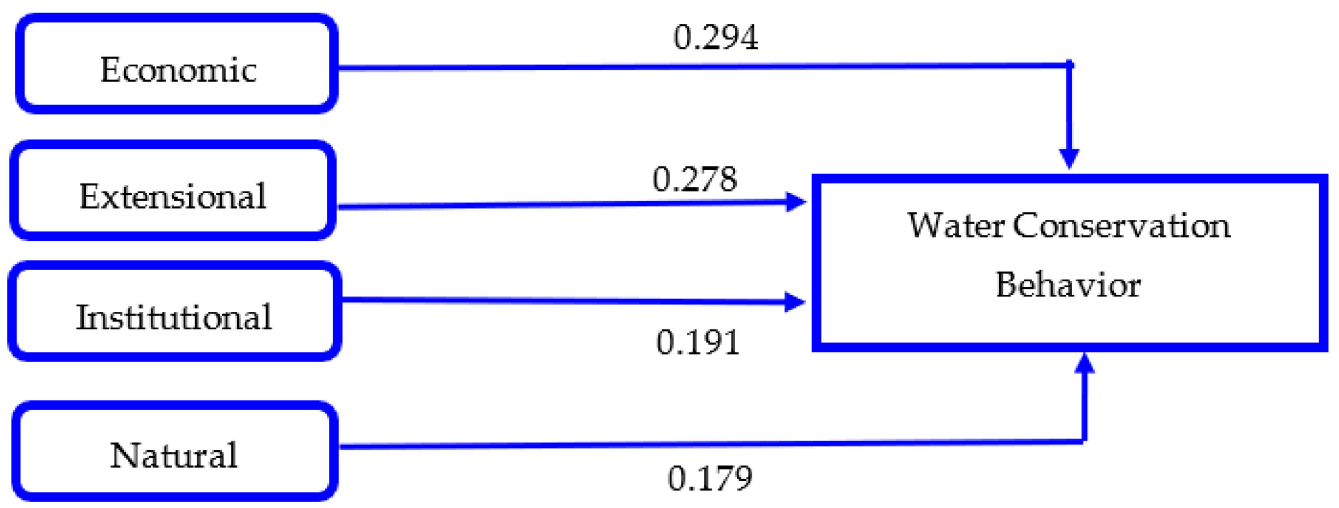

Figure 3. The explored model of the WCBs of wheat farmers.

Table 8. Multivariate regression.

\begin{tabular}{cccccccccc}
\hline Rank & Variable & $\mathbf{R}$ & $\mathbf{R}^{\mathbf{2}}$ & $\mathbf{R}^{\mathbf{2}}$ Adjusted & $\mathbf{B}$ & $\boldsymbol{\beta}$ & $\mathbf{t}$ & Sig & Durbin Watson \\
\hline & Constant & & & & & -17.508 & & -2.238 & 0.026 \\
1 & Economic X1 & 0.529 & 0.28 & 0.278 & 1.783 & 0.294 & 6.381 & 0 & 0 \\
2 & Extensional X2 & 0.634 & 0.402 & 0.398 & 2.732 & 0.278 & 6.615 & 0 & 1.887 \\
3 & Institutional X3 & 0.665 & 0.443 & 0.438 & 0.925 & 0.191 & 4.096 & 0 & 0 \\
4 & Natural X4 & 0.682 & 0.446 & 0.46 & 1.005 & 0.179 & 3.89 & 0 \\
\hline
\end{tabular}

The first variable of the regression equation is the first factor with 7 items, which has the most important role in the dependent variable. Based on this, it can be said that the first factor alone explained $28 \%$ of the variance in the WCBs of wheat farmers. The second factor, with a correlation coefficient and a determination coefficient of 20.2 , is the second variable of the equation, which together with the first factor, determines a total of $40.2 \%$ of the variance in the dependent variable. The third factor, as the third variable in the regression equation, along with the first and second factors, explained $44.3 \%$ of the variance in the WCBs of wheat farmers. Finally, the fourth factor with a determination coefficient of 2.3, together with the first three factors, captured $44.6 \%$ of the variance in the dependent variable (Table 8).

\section{Discussion}

\subsection{Factors Affecting WCBs Using Exploratory Factor Analysis}

In this study, we first identified the effective factors of wheat farmers' WCBs using exploratory factor analysis. Then, we examined the impact of each factor on wheat farmers' WCBs using regression. Therefore, due to the lack of appropriate frameworks, by examining the impact of identified factors on WCBs, we provided an appropriate framework to explain this behavior. The multidimensional structure of WCBs that emerges from our analysis is created by the data collected from participants (wheat farmers) and supported by statistical models. In this study, 65 indicators were used to identify the factors affecting wheat farmers' WCBs in Bukan Township, and the data were analyzed using a factor analysis model. According to Kaiser Criterion, seven factors had eigenvalues greater than 1. After factor rotation by the Varimax method, the variables related to the factors affecting the environmental behavior of wheat farmers were classified into seven groups. Then, using stepwise regression, four factors (economic, extensional, institutional, and natural) determined a total of $44.6 \%$ of the variance in the dependent variable. In response to the identification of measures that enhance water conservation practices, many interviewees argue that current policies on the sustainability of water resources are weak and in some cases at odds with the economic interests of farmers. Based on these results, it is suggested that the Ministry of Agriculture, as the main trustee in farmers-related issues, can have a 
crucial role in the sustainability of water resources in the region by amending and enacting the laws that encourage farmers to protect and save water resources.

\subsection{Factors Affecting WCBs Using Regression Analysis}

The correlation outcomes revealed a positive and important connection between the identified variables and WCBs. Furthermore, the consequences of regression analysis showed that the economic factor was one of the most important predictors of WCBs among other variables. Paying attention to the economic justification of water resources protection methods (such as granting facilities, reducing costs, insurance, etc.) can encourage farmers to use these methods. It is worth mentioning that although previous research has addressed the role of economic factors in the adoption of water conservation technologies [49], none of these studies has considered the role of the economic factor in WCBs, which is one of the limitations of the previous behavioral models. This limitation was tackled by using the present exploratory model. In addition, the extensional factor was the second influential variable on WCBs after the economic factor. These results show that the quality of services provided by the Agricultural Jihad Organization for wheat farmers (such as holding training classes, improving knowledge and awareness, promoting optimal products, etc.) can have a significant impact on farmers' behaviors in the field of sustainable protection of water resources. Agricultural Jihad Organization can play a crucial role in the sustainability resources of water in the region now and in the future by continuing the current measures and improving the quality of these services. Although the role of extension activities has been considered in the study by Valizadeh et al. [42], the most important factor identified in this study, namely the economic factor, has been overlooked, which is one of the key findings of the present article. Policymakers can use perceived attitudes, mental norms, and perceived behavioral controls to direct farmers' intentions and behaviors to maintain ecological gains in vulnerable areas of the environment through WCT programs. Therefore, this procedure can enhance the sustainability of environmental and ecological reconstruction programs.

It can be considered that the rise in the need for agricultural water in Iran has accelerated year by year as a result of growth in population and economic development [50]. Temporal and spatial variability of hydrological changes due to human activities in the river basin can influence the quality and quantity of water. An important challenge is that integrated water resources management must deal with complex water issues to maximize economic and social health in a reasonable way without compromising the sustainability of crucial ecosystems. Even if the Iranian government adopts a new paradigm for water resources management involving the water resources law, integrated implementation of water resources management might face technological, managerial, and economic challenges. Although economists have long argued that the main driver of water conservation behavior among farmers is economic factors, they are not statistically significant per se. Examining the relationship between the improved attitudes and behaviors, it can be said that economic factors are significant and will have a moderating effect on farmers' protective attitudes. Stronger conservation attitudes and higher incomes are likely to lead to more water conservation behavior by farmers. However, farmers with higher incomes tend to have less attitudes towards conservation measures [51]. Based on the results, the institutional factor is the third influential variable on WCBs. This finding indicates that large institutions related to the agricultural sector (Ministry of Agriculture) should encourage farmers to implement water conservation methods in agricultural processes by setting appropriate laws and policies. This factor was one of the factors that were suggested in Darkwah et al.'s [52] study as factors affecting WCBs. As shown by Xie et al. [53], the use of spatial patterns and heterogeneity is effective in water conservation behaviors. According to their findings, prediction involves using classification or regression models learned from training datasets to estimate values for unlabeled locations in a geographic domain (e.g., land use classification, crop yield prediction). Outlier analysis identifies data points in a dataset that are more likely to be generated by a distribution other than the major or 
dominant distribution (e.g., water flow anomaly). As a result, the goal of teleconnection analysis is to find closely related events or phenomena that are spatially separated from one another (e.g., El Nino).

Finally, the natural factor was the fourth and last variable that had a positive and notable influence on WCBs according to the regression results. The results of this study revealed that the natural conditions, climate, and topography of the study area can be effective in farmers' decisions to use methods that are compatible with conserving water resources although in some cases can slow down the environmental measures. This is also important from ecosystem services viewpoint, as climate and topography are regulating services. Farmers value on-farm ecosystem services, according to previous research, and farmer related factors such as lack of awareness and lack of access to adequate information have been linked to non-participation in conservation-based programs [54]. The findings of this study are consistent with the results of Asah et al. [55], which addressed the function of ecosystems in conservation behaviors, although the role of other factors was not addressed in this study. In general, these results showed the potential of the studied factors to explain wheat farmers' WCBs. Although the framework of the present study cannot solve all the existing problems in the field of water resources saving, according to the findings, it can be considered by managers and policymakers for wheat WCBs. In addition, it is recommended to present a WCBs model that can be applied to other types of agriculture in future research.

\section{Conclusion and Policy Implications}

This study identified and examined the impact of different factors on WCB. The findings contributed to expanding our understanding of important factors affecting WCBs among wheat farmers. In this regard, the findings indicate that economic, extensional, institutional, and natural factors must be considered when investigating WCBs. The results of this study contribute to a practical aspect according to which, in addition to considering economic factors in the study of water conservation measures, it is essential to pay attention to extension services. This study can also be beneficial for agricultural decision-makers who want to optimize water consumption and improve precautionary behaviors to combat the growing water deficiency in Iran. The current study could also have considerable functional implications for agricultural decision-makers, agricultural implementing companies, people, and organizations that are somehow associated with the application and dissemination of these new water-saving technologies. Moreover, it is recommended that to support farmers to adopt water conservation methods, government policy programs should notify farmers about the negative influences of water resource degradation and the benefits of water conservation. Furthermore, to prevent adverse outcomes, farmers' water consumption should be considered significantly. In addition, creating a water market in the agricultural sector can have several economic benefits so that it can be a promising solution to increase the economic efficiency of water and revenue, and reduce the risk of revenue for water buyers and sellers.

The advantage of the current study was the simultaneous analysis of a broad range of factors that could describe the water conservation behavior of wheat producers. Watersaving behavior has led to new prospects, such as the description of factors with low-level potential for usage in public information campaigns aimed at increasing water conservation behavior in the agricultural sector worldwide. In addition, the findings of this study helped identify communication messages and policies that focus on farmers to encourage water conservation practices in Iran as well as other developing countries with water shortages in the agricultural sector. Addressing water preservation issues is crucial for guaranteeing the sustainable management of water resources, and this is especially important given the climate change. Using the findings of this research, by combining variables related to socio-economic, household, individual, and agricultural perceptions, it is possible to effectively explain the WCB approval by farmers in Iran and other parts of the world. Overall, it can be concluded that an integrated approach to analyzing WCBs appropriation 
adequately defines the decisions, opportunities, and constraints faced by farmers and enables targeted agricultural management.

In order to achieve water resource sustainability, the study's findings have some practical implications for water resource managers, environmental and natural resource managers, interventionist organizations, and even farmers. Psychological, social, and personal identity factors all play a role in water resource management.

As a result, some policy concepts are presented in this section to facilitate the application of study results in administrative areas (resource management in Bukan Township, Iran):

- Water resource managers and public assistance units of relevant Iranian organizations should understand the agricultural community's values and consider their role in water resource management.

- Those in charge of water resources management in the Ministry of Jihad for Agriculture, institutions, and organizations should develop a comprehensive plan to raise awareness about the negative consequences of water resource loss.

- Farmers' sense of personal commitment to mitigate the negative effects of the water crisis will dwindle if they refuse to accept any responsibility for water problems and blame all issues and problems on government mismanagement. Change agents, such as agricultural extension organizations and community-based units from related groups (for example, Iran's Ministry of Energy), can effectively encourage farmers.

- Managers and officials in charge of water resource management should consider not only the importance of saving water for farmers, but also the importance of this for other stakeholders. This is because comprehending the significance of these stakeholders can aid water resource managers in anticipating and resolving conflicts. According to the findings of this study, the implications of environmental management for the international domain are as follows:

- Use initiatives based on the farmers' needs for ecosystem services. Farmers who use water-saving technologies, for example, should be more motivated than those who use ineffective technologies.

- A policy centered on raising awareness toward ecosystem services can have a ripple effect and improve other behavioral patterns of farmers towards other issues like resource management, conservation of biodiversity, and so on.

- Findings of this research show that a deep perception of the farmer's desire and ability to utilize environmental management practices and the current level of their interaction with international consultation and support to increase suitable interaction approaches to achieve sustainable water resources management and environmental management is essential.

- In general, farmers should be supported and empowered to benefit from long-term environmental programs in the face of unpredictable challenges (e.g., climate change and global warming).

- Given the long-term nature of community efforts to make the international environment more sustainable, developing a strategy that focuses on determining farmers' core values in this regard can be a worthwhile investment. Although this study tried to examine the importance of each of the factors affecting WCBs, there are some limitations. First, there is a variety of psychological and social variables that could enhance the captured variance of WCBs. Other researchers in the future could use them to explain WCBs. Due to time and economic constraints, a questionnaire was used to collect data. It is suggested that in future studies, other statistical methods, especially structural equations, be used to confirm the model extracted from this research for data analysis and accurate results. In addition, this study has collected some location information such as townships of the samples. However, the results are presented in a spatially aggregated manner, and spatial-related patterns have not been analyzed. One major phenomenon in space is spatial heterogeneity, which means different regions tend to show different patterns. Therefore, it is recommended that 
this issue should be analyzed in future studies to improve our understanding and support for policy-making.

Author Contributions: Conceptualization, methodology, software, formal analysis, data curation, writing—original draft preparation, Y.M.; validation, investigation, resources, writing—review and editing, visualization, supervision, and project administration, S.C., H.S. and H.A.; formal analysis, writing-review and editing, C.-V.M., A.-H.V. and A.K. All authors have read and agreed to the published version of the manuscript.

Funding: This research received no external funding.

Institutional Review Board Statement: Not applicable.

Informed Consent Statement: Not applicable.

Data Availability Statement: Raw data were generated at Tarbiat Modares University. We confirm that the data, models, or methodology used in the research are proprietary, and derived data supporting the findings of this study are available from the first author on request.

Acknowledgments: This research paper was partly funded by the Strategic Priority Research Program of Chinese Academy of Sciences (Grant No. XDA20060303) and the Chinese Academy of Sciences President's International Fellowship Initiative (PIFI grant no. 2021VCA0004).

Conflicts of Interest: The authors declare no conflict of interest.

\section{References}

1. Alqadi, M.; Al Dwairi, A.; Dehnavi, S.; Margane, A.; Al Raggad, M.; Al Wreikat, M.; Chiogna, G. A novel method to assess the impact of a government's water strategy on research: A case study of Azraq Basin, Jordan. Water 2021, 13, 2138. [CrossRef]

2. Crites, R.; Beggs, R.; Leverenz, H. Perspective on land treatment and wastewater reuse for agriculture in the Western United States. Water 2021, 13, 1822. [CrossRef]

3. Torres-Bagur, M.; Ribas, A.; Vila-Subirós, J. Understanding the key factors that influence efficient water-saving practices among tourists: A mediterranean case study. Water 2020, 12, 2083. [CrossRef]

4. Yazdanpanah, M.; Hayati, D.; Hochrainer-Stigler, S.; Zamani, G.H. Understanding farmers' intention and be-havior regarding water conservation in the Middle-East and North Africa: A case study in Iran. J. Environ. Manag. 2014, 135, 63-72. [CrossRef] [PubMed]

5. Statistical Center of Iran. Statistical Yearbook 2013-2014. 2014. Available online: http://www.amar.org.ir/Portals/0Files/ fulltext/1393/n_tsokkk_93-v3.pdf (accessed on 29 April 2017).

6. Maleksaeidi, H.; Keshavarz, M. What influences farmers' intentions to conserve on-farm biodiversity? An ap-plication of the theory of planned behavior in fars province, Iran. Glob. Ecol. Conserv. 2019, 20, e00698. [CrossRef]

7. Azadi, Y.; Yazdanpanah, M.; Mahmoudi, H. Understanding smallholder farmers' adaptation behaviors through climate change beliefs, risk perception, trust, and psychological distance: Evidence from wheat growers in Iran. J. Environ. Manag. 2019, 250, 109456. [CrossRef] [PubMed]

8. Pakmehr, S.; Yazdanpanah, M.; Baradaran, M. Explaining farmers' response to climate change-induced water stress through cognitive theory of stress: An Iranian perspective. Environ. Dev. Sustain. 2021, 23, 5776-5793. [CrossRef]

9. Mostafavi, H.; Kambouzia, J. Impact of climate change on the distribution of brown trout, Salmo trutta Linnaeus, 1758 (Teleostei: Salmonidae) using ensemble modelling approach in Iran. Iran. J. Ichthyol. 2019, 6, 73-81.

10. Mirnezami, S.J.; De Boer, C.; Bagheri, A. Groundwater governance and implementing the conservation policy: The case study of Rafsanjan Plain in Iran. Environ. Dev. Sustain. 2020, 22, 8183-8210. [CrossRef]

11. Vaghefi, S.A.; Keykhai, M.; Jahanbakhshi, F.; Sheikholeslami, J.; Ahmadi, A.; Yang, H.; Abbaspour, K.C. The future of extreme climate in Iran. Sci. Rep. 2019, 9, 1-11. [CrossRef]

12. Ghalibaf, M.B.; Moussavi, Z. Development and environment in Urmia Lake of Iran. Eur. J. Sustain. Dev. $2014,3,219$.

13. Rezaei, R.; Safa, L.; Ganjkhanloo, M.M. Understanding farmers' ecological conservation behavior regarding the use of integrated pest management- an application of the technology acceptance model. Glob. Ecol. Conserv. 2020, 22, e00941. [CrossRef]

14. Moghadam, M.T.; Raheli, H.; Zarifian, S.; Yazdanpanah, M. The power of the health belief model (HBM) to predict water demand management: A case study of farmers' water conservation in Iran. J. Environ. Manag. 2020, 263, 110388. [CrossRef] [PubMed]

15. Machovina, B.; Feeley, K.J.; Ripple, W.J. Biodiversity conservation: The key is reducing meat consumption. Sci. Total. Environ. 2015, 536, 419-431. [CrossRef] [PubMed]

16. Zhang, Q.; Xiao, H.; Duan, M.; Zhang, X.; Yu, Z. Farmers' attitudes towards the introduction of agri-environmental measures in agricultural infrastructure projects in China: Evidence from Beijing and Changsha. Land Use Policy 2015, 49, 92-103. [CrossRef]

17. Fu, Y.; Wu, W.; Gao, J. Simulation and conservation of the end use water based on behaviour intervention mod-elling. Procedia Eng. 2015, 119, 761-770. [CrossRef] 
18. Dolnicar, S.; Hurlimann, A.; Grün, B. WCB in Australia. J. Environ. Manag. 2012, 105, 44-52. [CrossRef]

19. Markle, G.L. Pro-environmental behavior: Does it matter how it's measured? Development and validation of the proenvironmental behavior scale (PEBS). Hum. Ecol. 2013, 41, 905-914. [CrossRef]

20. Chen, X.; Peterson, M.N.; Hull, V.; Lu, C.; Hong, D.; Liu, J. How perceived exposure to environmental harm in-fluences environmental behavior in urban China. Ambio 2013, 42, 52-60. [CrossRef]

21. Blok, V.; Wesselink, R.; Studynka, O.; Kemp, R. Encouraging sustainability in the workplace: A survey on the pro-environmental behaviour of university employees. J. Clean. Prod. 2015, 106, 55-67. [CrossRef]

22. Despotović, J.; Rodić, V.; Caracciolo, F. Factors affecting farmers' adoption of integrated pest management in Serbia: An application of the theory of planned behavior. J. Clean. Prod. 2019, 228, 1196-1205. [CrossRef]

23. Ge, J.; Sutherland, L.-A.; Polhill, J.G.; Matthews, K.; Miller, D.; Wardell-Johnson, D. Exploring factors affecting on-farm renewable energy adoption in Scotland using large-scale microdata. Energy Policy 2017, 107, 548-560. [CrossRef]

24. Janmaimool, P.; Denpaiboon, C. Evaluating determinants of rural Villagers' engagement in conservation and waste management behaviors based on integrated conceptual framework of Pro-environmental behavior. Life Sci. Soc. Policy 2016, 12, 1-20. [CrossRef] [PubMed]

25. Van Dijk, W.F.; Lokhorst, A.M.; Berendse, F.; de Snoo, G.R. Factors underlying farmers' intentions to perform unsubsidised agri-environmental measures. Land Use Policy 2016, 59, 207-216. [CrossRef]

26. Wang, P.; Liu, Q.; Qi, Y. Factors influencing sustainable consumption behaviors: A survey of the rural residents in China. J. Clean. Prod. 2014, 63, 152-165. [CrossRef]

27. Noori, S.H.; Jamshidi, A.R.; Jamshidi, M.; Moghadam, Z.H.; Fathi, E. Survey on factors affecting the acceptance of Soil Conservation Measures, a Step Towards Sustainable Agriculture; Case Study: Township of Shirvan and Chardavol. Iran. J. Agric. Econ. Dev. Res. (IJAEDR) 2014, 45, 195-205.

28. Malawska, A.; Topping, C.J.; Nielsen, H. Ørsted Why do we need to integrate farmer decision making and wildlife models for policy evaluation? Land Use Policy 2014, 38, 732-740. [CrossRef]

29. Cauberghe, V.; Vazquez-Casaubon, E.; Van de Sompel, D. Perceptions of water as commodity or uniqueness? The role of water value, scarcity concern and moral obligation on conservation behavior. J. Environ. Manag. 2021, 292, 112677. [CrossRef]

30. Saby, L.; Nelson, J.D.; Band, L.E.; Goodall, J.L. Nonpoint source water quality trading outcomes: Land-scape-scale patterns and integration with watershed management priorities. J. Environ. Manag. 2021, 294, 112914. [CrossRef]

31. Aprile, M.C.; Fiorillo, D. Water conservation behavior and environmental concerns: Evidence from a repre-sentative sample of Italian individuals. J. Clean. Prod. 2017, 159, 119-129. [CrossRef]

32. Asfaw, D.; Neka, M. Factors affecting adoption of soil and water conservation practices: The case of Wereillu Woreda (District), South Wollo Zone, Amhara Region, Ethiopia. Int. Soil Water Conserv. Res. 2017, 5, 273-279. [CrossRef]

33. Mohammadinezhad, S.; Ahmadvand, M. Modeling the internal processes of farmers' water conflicts in arid and semi-arid regions: Extending the theory of planned behavior. J. Hydrol. 2020, 580, 124241. [CrossRef]

34. Rezaei, A.; Salmani, M.; Razaghi, F.; Keshavarz, M. An empirical analysis of effective factors on farmer's adaptation behavior in water scarcity conditions in rural communities. Int. Soil Water Conserv. Res. 2017, 5, 265-272. [CrossRef]

35. Yazdanpanah, M.; Feyzabad, F.R.; Forouzani, M.; Mohammadzadeh, S.; Burton, R.J. Predicting farmers' water conservation goals and behavior in Iran: A test of social cognitive theory. Land Use Policy 2015, 47, 401-407. [CrossRef]

36. Shiferaw, B.A.; Okello, J.; Reddy, R.V. Adoption and adaptation of natural resource management innovations in smallholder agriculture: Reflections on key lessons and best practices. Environ. Dev. Sustain. 2009, 11, 601-619. [CrossRef]

37. Gouldson, A.; Hills, P.; Welford, R. Ecological modernisation and policy learning in Hong Kong. Geoforum 2008, 39, 319-330. [CrossRef]

38. Daloglu, I.; Nassauer, J.I.; Riolo, R.L.; Scavia, D. Development of a farmer typology of agricultural conservation behavior in the American Corn Belt. Agric. Syst. 2014, 129, 93-102. [CrossRef]

39. Moshtagh, M.; Mohsenpour, M. Community viewpoints about water crisis, conservation and recycling: A case study in Tehran. Environ. Dev. Sustain. 2019, 21, 2721-2731. [CrossRef]

40. Momenpour, Y.; Sedighi, H.; Choobchian, S. Structural analysis role of educational-extension and psychological components on environmental behavior of wheat growers in west Azerbaijan province, Iran (case Study: Bukan Township). J. Agric. Ext. Educ. Res. 2017, 9, 27-39.

41. Liu, J.; Qu, H.; Huang, D.; Chen, G.; Yue, X.; Zhao, X.; Liang, Z. The role of social capital in encouraging residents' proenvironmental behaviors in community-based ecotourism. Tour. Manag. 2014, 41, 190-201. [CrossRef]

42. Valizadeh, N.; Bijani, M.; Abbasi, E. Farmers active participation in water conservation: Insights from a survey among farmers in southern regions of West Azerbaijan Province, Iran. J. Agric. Sci. Technol. 2018, 20, 895-910.

43. Dienes, C. Actions and intentions to pay for climate change mitigation: Environmental concern and the role of economic factors. Ecol. Econ. 2015, 109, 122-129. [CrossRef]

44. Krejcie, R.V.; Morgan, D.W. Determining sample size for research activities. Educ. Psychol. Meas. 1970, 30, 607-610. [CrossRef]

45. Étoré, P.; Jourdain, B. Adaptive optimal allocation in stratified sampling methods. Methodol. Comput. Appl. Probab. 2010, 12, 335-360. [CrossRef]

46. Nejadrahim, R.; Sahranavard, M.; Aminizadeh, A.; Delirrad, M. Snake envenomation in North-West Iran: A three-year clinical study. Int. J. Med. Toxicol. Forensic Med. 2019, 9, 31-38. 
47. Samuels, P. Advice on Exploratory Factor Analysis; Technical Report 2017; Birmingham City Business School-Research Gate: Birmingham, UK, 2017.

48. Liao, P.-Y. Optimal pricing strategy for queuing systems with capacity constraint problem. In Proceedings of the Third International Conference on Intelligent Information Hiding and Multimedia Signal Processing (IIH-MSP 2007), Kaohsiung, Taiwan, 26-28 November 2007; pp. 561-564.

49. Jha, S.; Kaechele, H.; Sieber, S. Factors influencing the adoption of water conservation technologies by small-holder farmer households in Tanzania. Water 2019, 11, 2640. [CrossRef]

50. Michel, D. Iran's impending water crisis. In Water, Security and US Foreign Policy; Routledge: Oxfordshire, UK, 2017 ; p. 168.

51. Zhou, Z.; Liu, J.; Zeng, H.; Zhang, T.; Chen, X. How does soil pollution risk perception affect farmers' pro-environmental behavior? The role of income level. J. Environ. Manag. 2020, 270, 110806. [CrossRef]

52. Darkwah, K.A.; Kwawu, J.D.; Agyire-Tettey, F.; Sarpong, D.B. Assessment of the determinants that influence the adoption of sustainable soil and water conservation practices in Techiman Municipality of Ghana. Int. Soil Water Conserv. Res. 2019, 7, 248-257. [CrossRef]

53. Xie, Y.; Eftelioglu, E.; Ali, R.Y.; Tang, X.; Li, Y.; Doshi, R.; Shekhar, S. Transdisciplinary foundations of geospatial data science. ISPRS Int. J. Geo-Inf. 2017, 6, 395. [CrossRef]

54. Girija, P.; Bellotti, B. Farmers value on-farm ecosystem services as important, but what are the impediments to participation in PES schemes? Sci. Total. Environ. 2015, 515, 12-19.

55. Asah, S.T.; Guerry, A.D.; Blahna, D.J.; Lawler, J.J. Perception, acquisition and use of ecosystem services: Human behavior, and ecosystem management and policy implications. Ecosyst. Serv. 2014, 10, 180-186. [CrossRef] 